\title{
IMF policy is blamed for contributing to Ebola epidemic
}

\author{
Anne Gulland
}

London

Short term economic policies advocated by the International Monetary Fund have exacerbated the epidemic of Ebola virus disease in west Africa, a study has said. ${ }^{1}$

Researchers at the London School of Hygiene and Tropical Medicine and the universities of Oxford and Cambridge looked at the fund's policies in regard to the three worst affected countries, Sierra Leone, Liberia, and Guinea. The weakness of these countries' health systems has often been highlighted as a reason for the rapid spread of the disease, and the researchers found that the IMF's policies had not allowed the three countries to invest in their health or education systems.

The fund has been providing economic support to Guinea for 21 years, Liberia for seven years, and Sierra Leone for 19 years. But researchers said that the conditions attached to the funding encouraged short term economic priorities. The conditions imposed by the IMF included reductions in government spending, prioritisation of paying back debt, and bolstering foreign exchange reserves. The IMF has incorporated "poverty-reduction expenditure" into its programmes, but all three countries failed to meet these targets in 2013, the year the first case of Ebola virus disease was recorded in Guinea.

The researchers said that the IMF often required caps on the public sector wage bill, thus affecting the recruitment of health workers. In Sierra Leone, for example, the number of community health workers was cut from 0.11 per 1000 population in 2004 to 0.02 in 2008 .

The IMF also advocates decentralised health systems, which the researchers said made it "difficult to mobilise coordinated, central responses to disease outbreaks." The researchers pointed out that from the early 2000s in Guinea the IMF promoted fiscal and administrative decentralisation, but an IMF mission five years later reported "governance problems" and noted that the quality of health service delivery had deteriorated.
"A major reason why the Ebola outbreak spread so rapidly was the weakness of healthcare systems in the region, and it would be unfortunate if underlying causes were overlooked," said the study's lead author, the sociologist Alexander Kentikelenis.

"Policies advocated by the IMF have contributed to underfunded, insufficiently staffed, and poorly prepared health systems in the countries with Ebola outbreaks," he said.

When the IMF announced a cash injection of $\$ 430 \mathrm{~m}$ ( $£ 275 \mathrm{~m}$; $€ 350 \mathrm{~m}$ ) to help rid west Africa of the virus its director, Christine Lagarde, said that it was good to increase "the fiscal deficit when it's a matter of curing the people." The researchers welcomed her comments but questioned her long term commitment to prioritising public health over public debt.

The IMF disputed the researchers' findings, saying that it was incorrect that healthcare expenditure had declined in the three affected countries. It also said that it did not require caps on public sector wages.

The fund said in a statement, "The fact is that prior to the Ebola outbreak Guinea, Sierra Leone, and Liberia were doing relatively well trying to overcome years of instability as they emerged from conflict, including civil wars that claimed hundreds of thousands of lives and had a devastating impact on social infrastructure. Sierra Leone, for example, had for the last few years been one of Africa's fastest growing economies."

The latest figures from the World Health Organization, dated 17 December, show that there have been 18603 cases of the disease and 6915 deaths. There have been 8356 cases in Sierra Leone, 7797 cases in Liberia, and 2416 in Guinea.

Kentikelenis A, King L, McKee M, Stuckler D. The International Monetary Fund and the Ebola outbreak. Lancet Global Health 21 Dec 2014, doi:10.1016/S2214-109X(14)70377-

Cite this as: BMJ 2014;349:97815

(c) BMJ Publishing Group Ltd 2014 